\title{
Seasonal and small-scale spatial variability of herbivory pressure on the temperate seagrass Posidonia oceanica
}

\author{
F. Tomas ${ }^{1, *}, \mathrm{X}$. Turon ${ }^{2}, \mathrm{~J}$. Romero ${ }^{1}$ \\ ${ }^{1}$ Departament d'Ecologia and ${ }^{2}$ Departament de Biologia Animal, Invertebrats, Universitat de Barcelona, Avenida, \\ Diagonal 645, 08028 Barcelona, Spain
}

\begin{abstract}
Despite increasing evidence that herbivory on seagrasses can be substantial in nearshore systems, there is only scarce experimental data on the direct quantification of seagrass removal by herbivores. To help fill this gap, and to evaluate the hypothesis that herbivory on the Mediterranean seagrass Posidonia oceanica (L.) Delile is generally low, we assessed the patterns of grazing pressure variability and its effects on seagrass in an undisturbed meadow in the NW Mediterranean. We quantified herbivore density and grazing pressure through both direct (tethering experiment) and indirect (through marks of herbivore attacks) measurements. Although grazing varied greatly both temporally and spatially, our results show that whereas consumption by the sea urchin Paracentrotus lividus is relatively minor, $P$. oceanica is intensely grazed by the fish Sarpa salpa in summer. During this period, fish are very abundant at a depth of $5 \mathrm{~m}$, with consumption rates that temporarily exceed seagrass production, which is at its yearly minimum. This imbalance between consumption and production causes the appearance of mowed patches that can be seen from early summer to September; seagrass biomass is reduced by $50 \%$ in such patches. Through direct measurements of consumption, our study has revealed that $P$. oceanica consumption by herbivores can be substantial with respect to the total annual production and much higher than previously estimated through indirect measurements. Thus, it becomes apparent that estimation of consumption rates by indirect methods can grossly underestimate the importance of herbivory in seagrass ecosystems, which leads us to strongly advocate the use of direct methods whenever possible.
\end{abstract}

KEY WORDS: Fish grazing $\cdot$ Sea urchin grazing $\cdot$ Tethering $\cdot$ Feeding behaviour $\cdot$ Consumption rate Sarpa salpa $\cdot$ Paracentrotus lividus $\cdot$ Mediterranean

Resale or republication not permitted without written consent of the publisher

\section{INTRODUCTION}

Seagrass consumption by herbivores has generally been considered to be of minor importance in the trophic fluxes or in the interaction network of seagrass ecosystems (Nienhuis \& Van Ierland 1978, Thayer et al. 1984, Nienhuis \& Groenendijk 1986, Valiela 1995). However, there is increasing evidence that grazing on seagrasses is more important than previously accepted. While it would seem that seagrass grazing is higher in tropical systems (in the Caribbean, e.g. Valentine et al. 2000, Kirsch et al. 2002) than in temperate ones
(Mediterranean, e.g. Cebrián et al. 1996), these apparent latitudinal differences could be explained, at least in part, by methodological issues. Therefore, the importance of grazing is still far from being established. Despite this, little fieldwork has been carried out in this field and direct quantification of seagrass biomass removal by herbivores has only rarely been attempted (Valentine \& Heck 1999). Most data have been obtained from indirect measures (Cebrián \& Duarte 1998), which may not accurately represent herbivore consumption and thus could lead to misleading notions on the real importance of grazing in seagrass food webs. 
In fact, direct estimates have often revealed that grazing is more important than previously thought (e.g. Valentine et al. 2000, Kirsch et al. 2002, see Valentine \& Heck 1999 for a review).

Indeed, seagrass consumption by herbivores has generally not been considered important in Posidonia oceanica (L.) Delile, the most abundant species in the Mediterranean Sea. On average, it has been estimated to represent $2 \%$ of seagrass leaf production (Cebrián et al. 1996), although no direct measures are available (e.g. Alcoverro et al. 1997, Peirano et al. 2001). The 2 main macroherbivores in Posidonia oceanica meadows are the sea urchin Paracentrotus lividus (Lamarck) and the sparid fish Sarpa salpa (Linné) (Verlaque 1987, 1990). Whereas $P$. lividus is generally found in low densities in such meadows $\left(0\right.$ to 6 ind. $\mathrm{m}^{-2}$; see Boudouresque \& Verlaque 2001 for a review), S. salpa is very common (e.g. Harmelin-Vivien 1984, Velimirov 1984, Francour 1997). Most P. oceanica consumption (approximately $75 \%$ ) has been attributed to S. salpa activity (Cebrián et al. 1996) although the relative importance of fish grazing varies strongly both spatially and temporally (Alcoverro et al. 1997, Peirano et al. 2001). Yet, overgrazing by both herbivores is also known (Traer 1980, Verlaque \& Nédelec 1983, Verlaque 1990, Ruiz et al. 2001).

Moreover, intense grazing on Posidonia oceanica by Sarpa salpa appears to be a relatively common phenomenon in shallow waters during summer months (see Verlaque 1990), which seems to be associated with the reproductive behaviour of this fish. During winter, $S$. salpa stay in deeper waters (40 to $45 \mathrm{~m}$ ) for spawning and shelter, whereas when water is warmer, they are more abundant in shallow waters. At the end of summer, just before descending to spawn to deeper waters, fish feeding activity peaks (Verlaque 1990), which is probably linked to a higher metabolic requirement for reproduction (Laevastu \& Hayes 1981). However, to our knowledge, no study has directly assessed the variability and magnitude of such intense fish grazing events, as well as their potential effects on the seagrass.

Here we report the findings of a study aimed at examining patterns of herbivore consumption and its effects on the seagrass Posidonia oceanica in an undisturbed meadow in the NW Mediterranean through both direct and indirect measurements. Our specific goals were (1) to quantify and compare temporal and bathymetric variability of macroherbivore populations (the common sea urchin Paracentrotus lividus and the sparid fish Sarpa salpa), (2) to assess temporal and bathymetric variability of herbivore pressure through indirect estimates, (3) to directly quantify and compare the proportion of seagrass production consumed by the main macroherbivores during the period of highest fish grazing pressure (in summer) by means of a tethering experiment and (4) to estimate the magnitude and variability of intense fish grazing events and their impact on seagrass.

\section{MATERIALS AND METHODS}

Study site. The study was carried out in a Posidonia oceanica meadow located in the Medes Islands Marine Reserve (NE coast of Spain, NW Mediterranean Sea, $42^{\circ} 2^{\prime} \mathrm{N}, 3^{\circ} 13^{\prime} \mathrm{E}$ ) between depths of 5 and $10 \mathrm{~m}$ (see Manzanera et al. 1998, Alcoverro et al. 2000 for a more detailed description of the site). This meadow is continuous between a depth of 5 and $10 \mathrm{~m}$, and extends in a more patchy form towards deeper water; shoot density values range from between 600 and 450 shoots $\mathrm{m}^{-2}$ at depths of 5 and $10 \mathrm{~m}$, respectively (Romero et al. 1999) (Fig. 1).

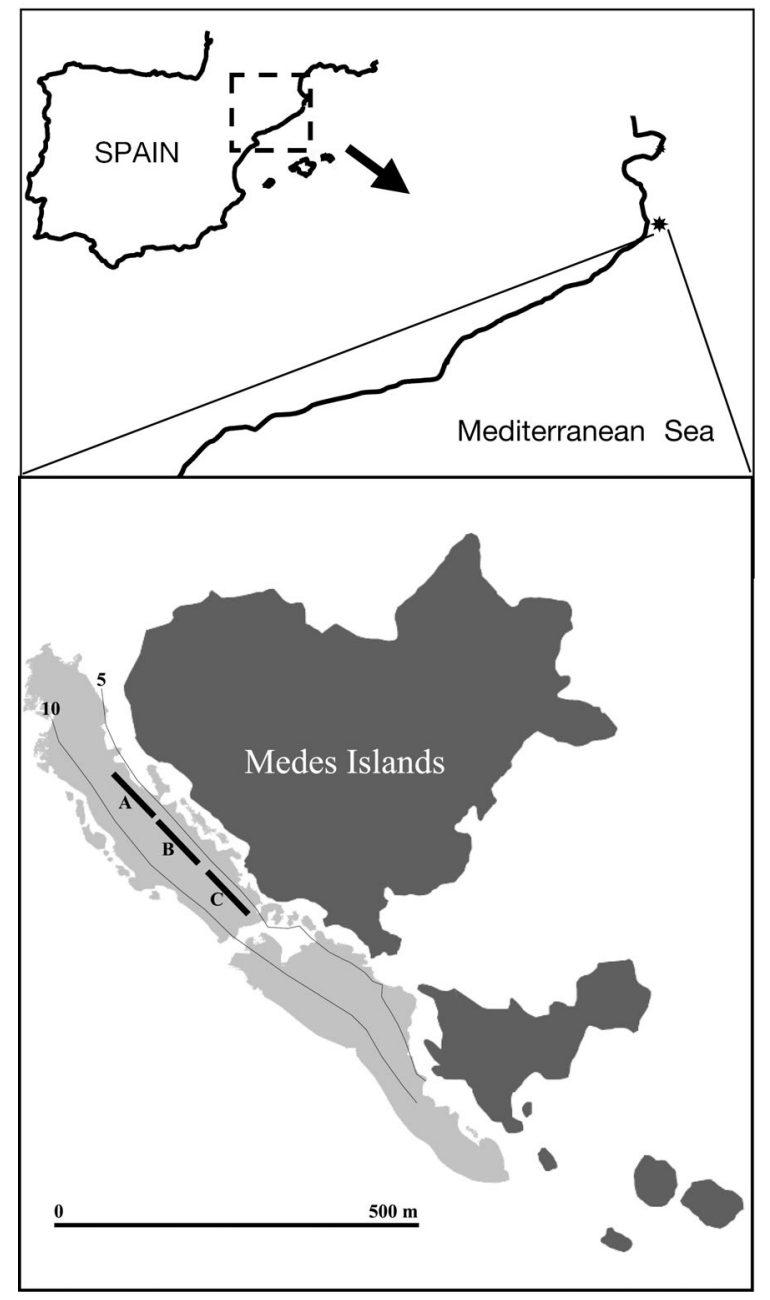

Fig. 1. Study site. Posidonia oceanica meadow (light grey) at Medes Islands Marine Reserve (NW Mediterranean). Locations of areas (A, B, C) studied and depth lines (5 and $10 \mathrm{~m}$ ) are shown 
Herbivore abundance. Given that the density of the sea urchin population in this meadow is relatively constant over time (Tomas et al. 2004), we conducted measurements of sea urchin abundance in May 2002, September 2002 and September 2003. Each time, we sampled randomly placed $0.25 \mathrm{~m}^{2}$ quadrats on transects positioned at 5 and $10 \mathrm{~m}$ depths (40 quadrats at each depth). All Paracentrotus lividus found in the quadrats were counted and measured (test diameter without spines, TD) to the nearest $1 \mathrm{~mm}$ using Vernier callipers.

Estimates of abundance of the herbivorous fish Sarpa salpa were performed every 2 mo between March 2002 and September 2003 at depths of 5 and $10 \mathrm{~m}$ using the visual transect census method (Harmelin-Vivien et al. 1985, Francour 1997). All S. salpa encountered along randomly located $50 \mathrm{~m}$ long $\times$ $5 \mathrm{~m}$ wide transects (García-Rubies \& Zabala 1990, García-Rubies 1997) were counted, and their size (total length, TL) estimated according to García-Rubies (1999). Within a $1 \mathrm{wk}$ period, 4 to 5 replicate measures were made; each time, 5 transects were surveyed at each depth. All fish counts were performed at the same time of day (approximately between 10:00 and 13:00 h) to diminish possible variability due to differences in fish behaviour (Spyker \& Van Der Berghe 1995).

Fish density was estimated by pooling the data from the 5 transects performed each day and expressed as the number of individuals per $100 \mathrm{~m}^{2}$. For statistical analysis, the different days of sampling were considered as replicates (i.e. $\mathrm{n}=4$ to 5 ). In addition, as different size classes feed differently (Verlaque 1990, Havelange et al. 1997), we divided counted fish into 1 of 2 size categories. On the one hand, we grouped all adult fish (i.e. TL $\geq 13 \mathrm{~cm}$ ) together, which are effective seagrass grazers. and on the other hand, we pooled young fish (i.e. TL $<6 \mathrm{~cm}$, planktivorous) and juveniles (i.e. $\mathrm{TL}=6$ to $12 \mathrm{~cm}$ ), which feed mostly on epiphytic red algae.

Since we observed a strong spatial heterogeneity in grazing pressure exerted by fish (see 'Results'), we wanted to test whether fish abundance exhibited a spatial distribution that corresponded to the spatial patchiness observed in fish grazing. To this end, during the summer months of 2002 and 2003, the counts of fish at a depth of $5 \mathrm{~m}$ were done separately in 3 replicated areas (A, B and C in Fig. 1), where other measurements had been carried out during this study (see below, 'Estimates of grazing pressure'). The 3 areas were between 5 and $6 \mathrm{~m}$ deep, and each area was approximately $100 \mathrm{~m}$ long and 6 to $10 \mathrm{~m}$ wide. In each area, we surveyed 2 transects, $50 \mathrm{~m}$ long $\times 5 \mathrm{~m}$ wide, in $5 \mathrm{~d}$ within the same week. Fish density was expressed as individuals per $100 \mathrm{~m}^{2}$ (replicates are $\mathrm{n}=5$ sampling events).
Estimates of grazing pressure. Indirect approach: We first estimated grazing pressure indirectly as the frequency of herbivore attacks. To this end, 50 Posidonia oceanica shoots were collected haphazardly by SCUBA divers at 2 depths, 5 and $10 \mathrm{~m}$, every 2 mo between March 2002 and September 2003. Shoots harvested within an area approximately 250 to $300 \mathrm{~m}$ long $\times 5 \mathrm{~m}$ wide (to fit the area of fish censuses) were kept in seawater and transported to the laboratory for processing. In the laboratory, the length of leaves was measured and the marks left by herbivores were identified and counted, since herbivore bites left on $P$. oceanica leaves are clearly and easily distinguishable (Boudouresque \& Meinesz 1982, Alcoverro et al. 1997). As indicators of fish grazing pressure, we used the total shoot length (i.e. the sum of lengths of all leaves within a shoot, $\mathrm{cm}$ ) and the number of bites per $\mathrm{cm}$ of leaf length (bites $\mathrm{cm}^{-1}$ leaf).

Experimental approach: To directly quantify grazing pressure, we carried out a tethering experiment (e.g. Mariani \& Alcoverro 1999, Kirsch et al. 2002) during summer 2002, when Sarpa salpa is abundant (Verlaque 1990, Francour 1997, this study).

Posidonia oceanica shoots were harvested between depths of 5 and $6 \mathrm{~m}$, selecting shoots with leaves intact (i.e. no grazing scars or broken); if all shoots had marks, we cut the tips of the leaves, leaving only the intact portions. After recording the length of each leaf $( \pm 0.5 \mathrm{~cm})$, individual shoots were tagged and attached to a tent peg with a plastic cable-tie. Pegs were then inserted into the sediment; maximum care was taken to ensure that leaves were neither above nor below the average height of the leaf canopy. During the manipulation period, shoots were kept underwater to avoid potential stress and loss of epiphytes, thus minimizing potential tethering artefacts.

To assess the spatial variance in grazing, we studied the 3 replicated areas (A, B and C) defined above (see Fig. 1) separately. Three groups (lines) of 5 tethered shoots each, anchored to the bottom with the tent pegs and connected by a thin rope were placed within each area (i.e. a total of 15 shoots per area). Shoots within a line were separated from each other by approximately $1.5 \mathrm{~m}$, and lines were placed approximately 10 to $15 \mathrm{~m}$ apart. After $10 \mathrm{~d}$, tethered shoots were retrieved and replaced by new ones. The first set of shoots was deployed on 22 July, and subsequent replacement dates were 1 August and 11 August 2002; the experiment ended on 21 August 2002. Retrieved shoots (i.e. 45 shoots each time) were transported to the laboratory, and leaf length and width as well as number and size of bite marks were recorded for each shoot.

Leaf tissue loss rate was estimated by subtracting the leaf area remaining after $10 \mathrm{~d}$ from the initial measurement of leaf area (i.e. initial length $\times$ width) 
and was expressed in $\mathrm{cm}^{2}$ shoot $^{-1} \mathrm{~d}^{-1}$ (Kirsch et al. 2002). When bite marks did not cut the leaf tip straight or when bites were on the sides of the leaf, an individual estimate of leaf area removed by each of these bites was calculated. The species responsible for each bite was identified according to the type of bite mark. All leaf losses could be attributed to a particular species and we were therefore able to separately estimate seagrass removal rates for sea urchins and fish. Although we did not specifically examine whether tethered shoots still conserved the capacity to grow, leaf elongation is very low in summer and only takes place in young leaves (those least submitted to grazing; Alcoverro et al. 1995). Moreover, growth in detached Posidonia oceanica shoots is seriously depressed (J. Romero unpubl. obs.).

Prior to the tethering experiment, a preliminary study (tethered shoots which remained underwater continuously for $16 \mathrm{~d}$, and which were checked daily) was carried out to test for other potential tethering artefacts, but nothing (e.g. tissue necrosis, loss of leaves) which could alter our results was observed. In any case, maximum care was taken to maintain the original natural condition and appearance of tethered shoots. In addition to integrating the tethered shoots into the leaf canopy, to rule out the possibility that grazers were avoiding or preferentially feeding on tethered shoots, we compared the number of fish bites per shoot of the tethered shoots with that in shoots randomly collected from depths between 5 and $6 \mathrm{~m}$ during the time at which the lines were deployed (Kirsch et al. 2002).

Mowed patch formation by herbivorous fish: In summer 2000 and 2001, we observed that an important part of the shallow meadow appeared to have been heavily grazed by Salpa sarpa. Therefore, in the summer of 2002, we assessed the magnitude, spatial variability and effect on the seagrass of this 'mowing' activity.

We characterised the abundance, size and spatial distribution of the heavily grazed areas (hereafter mowed patches) between depths of 5 and $6 \mathrm{~m}$ by setting 2 fixed transects along the total length of the meadow (i.e. approximately $300 \mathrm{~m}$ ) $10 \mathrm{~m}$ apart from each other, and measuring the sizes of mowed patches within the area delimited by the transects.

To assess the spatial variability of the formation of mowed patches, the same 3 replicated areas established for the tethering experiment were used (i.e. A, B and $C$, Fig. 1). To evaluate the effects of these intense grazing events on seagrass, we compared several measures of plant and epiphyte vitality within the mowed patches with those from shoots outside them; that is, areas not heavily grazed by Sarpa salpa. Within each area (A, B, C), 3 mowed patches were selected haphaz- ardly. For each mowed patch, a plot was marked within it. Another plot was marked outside the mowed patch, in the nearby ungrazed surroundings, resulting in 3 mowed plots and 3 ungrazed plots in each of areas A, B, and C. To keep the ungrazed areas as such during the experimental period, the plots from the ungrazed zones were protected with herbivore exclusion cages, $0.5 \times 0.5 \mathrm{~m}$, and $0.7 \mathrm{~m}$ high. The cages were delimited at the corners by iron bars, and fences were constructed with plastic mesh ( $2 \mathrm{~cm}$ pore size) attached to the seafloor with iron pegs; roofs consisted of plastic mesh $(5 \mathrm{~cm}$ pore size). Based on previous reports demonstrating the absence of caging effects (McGlathery 1995, Maciá 2000, Tomas et al. 2005), we did not use cage controls. Nonetheless, efforts were made to avoid interference, including weekly cleaning of the walls and replacement of roofs to prevent shading by epiphytes or cage mesh. In any case, cages only remained under water for $30 \mathrm{~d}$, so we did not expect to find any significant effects of cages on the plant parameters (e.g. Ruiz \& Romero 2001, Tomas et al. 2005).

To evaluate the impact on the plants within the grazed patches, we assessed the magnitude of biomass loss and its potential effect on other parameters. To this end, within each exclusion cage and within each of the selected mowed plots, 3 to 5 shoots were marked using a modified Zieman method (Romero 1989) at the beginning of the experiment (22 July 2002), collected at the end of the experiment (21 August 2002) and transported to the laboratory for further sorting. In the laboratory, the leaf length and width of each shoot was measured. Epiphytes from the collected shoots were removed by scraping with a razor blade (Alcoverro et al. 1997). Shoots and epiphytes were then dried $\left(70^{\circ} \mathrm{C}\right.$ to constant weight) and weighed separately. Leaf growth rate $\left(\mathrm{cm}^{2}\right.$ shoot $\left.{ }^{-1} \mathrm{~d}^{-1}\right)$ was determined by dividing the area of new tissue produced by the number of days elapsed since marking (i.e. 30 d). Epiphyte load was determined as the epiphyte biomass per unit leaf area $\left(\mathrm{g} \mathrm{DW}_{\mathrm{cm}}^{-2}\right)$. Shoot size was estimated as total shoot leaf biomass and as total shoot leaf area (g DW shoot $^{-1}$ and $\mathrm{cm}^{2}$ shoot $^{-1}$, respectively). The number of fish bites per leaf length (bites $\mathrm{cm}^{-1}$ leaf) and the frequency of shoots attacked by the 2 main herbivore species Sarpa salpa and Paracentrotus lividus were determined. In addition, we measured shoot density in the 9 mowed patches selected by placing three $40 \times 40 \mathrm{~cm}$ quadrats at random within the mowed patch, and counting all shoots within each quadrat.

Statistical analysis. To test for significant differences in time on Paracentrotus lividus density at a depth of $5 \mathrm{~m}$, we carried out a 1-way ANOVA (factor Time) on sea urchin density. To compare Sarpa salpa abundance at the 2 depths, we carried out a 2-way ANOVA with 
2 fixed orthogonal factors (Time and Depth) on adult (i.e. $\mathrm{TL} \geq 13 \mathrm{~cm}$ ) density. The same analysis was performed to test for significant differences in the variables used to document fish grazing pressure (i.e. number of fish bites per cm of leaf, and shoot length).

To test the hypothesis that the spatial distribution of fish was homogeneous during summer at a depth of $5 \mathrm{~m}$, we carried out a 2-way ANOVA with 2 orthogonal fixed factors (Time: i.e. July 2002, July 2003 and September 2003, and Area: i.e. the 3 areas delimited for the tethering experiment: A, B, C) on total fish density.

For the tethering experiment, to test the hypothesis that seagrass grazing varied both temporally and spatially, we conducted an ANOVA with 2 random orthogonal factors (Area and Time), as well as a nested factor (Line), on the percentage of offered shoot biomass removed by fish $\left(\mathrm{d}^{-1}\right)$. In this analysis, the different shoots were the independent replicates (5 per line). Whereas the factor Area represented spatial variability at a scale of a few hundred meters, Line represented spatial variability at a scale of tens of meters. The same analysis was carried out on the number of fish bites ( $\mathrm{cm}^{-1}$ leaf). To test for preferential feeding on tethered shoots, we performed a 2-sample $t$-test, on 2 independent samples: (1) the number of fish bites recorded on tethered shoots and (2) on shoots randomly collected in summer 2002.

To evaluate the effect of fish grazing on the mowed patches in comparison to ungrazed patches, we carried out ANOVA with 2 orthogonal factors (a fixed factor, Grazed or Ungrazed, and a random factor, Area), and a nested factor (Plots within area, $\mathrm{n}=3$ ) on shoot variables reflecting plant and epiphyte vitality. The replicates in this study are the different shoots analysed in each plot ( $n=3$ to 5 ). Due to the loss of the marked shoots from one of the mowed plots, to compare shoot production between mowed patches and ungrazed zones, we carried out a 2-way ANOVA with a fixed factor (Grazed vs Ungrazed) and a random factor (Area) using all the shoots as replicates.

In analyses involving fixed factors, when overall significant differences were detected, a posteriori pairwise comparisons of means were performed using the Student-Newman-Keuls (SNK; Zar 1989) comparison test. Prior to statistical analyses, normality and homogeneity of variance were checked for all data (Kolmogorov-Smirnov test and Cochran's test, respectively) and, when necessary, data were transformed as indicated in the 'Results' section. All differences were considered significant at $\mathrm{p}<0.05$ and marginally significant when $0.05<\mathrm{p}<0.10$. If we were unable to attain homoscedasticity (as indicated in the 'Results' section) even after trying several transformations of the variables studied, as samples were large, we con-
Table 1. Paracentrotus lividus. Mean and SEs for sea urchin density (ind $\mathrm{m}^{-2}$ ) recorded at the seagrass meadow at depths of 5 and $10 \mathrm{~m}$

\begin{tabular}{|lccc|}
\hline Depth & May 2002 & September 2002 & September 2003 \\
\hline $5 \mathrm{~m}$ & $2.6(0.4)$ & $4.8(0.8)$ & $3.2(0.7)$ \\
$10 \mathrm{~m}$ & $0(0)$ & $0(0)$ & $0(0)$ \\
\hline
\end{tabular}

sidered ANOVA to be robust to departures from this assumption (Underwood 1997, p. 193).

\section{RESULTS}

\section{Sea urchin and fish abundances}

The mean sea urchin population density at a depth of $5 \mathrm{~m}$ was $3.5 \pm 0.4(\mathrm{SE})$ ind. $\mathrm{m}^{-2}$ and consisted of adults only (mean TD = $67.3 \pm 0.5[\mathrm{SE}] \mathrm{mm}$ ). Sea urchins were completely absent at a depth of $10 \mathrm{~m}$ (Table 1). Although we observed some variability in urchin density, only marginally significant differences among sampling dates were detected (1-way ANOVA: $F=2.986$, $\mathrm{df}=2,116, \mathrm{p}=0.06$ ).

Fish density was generally higher at the shallower sites (Fig. 2), especially during spring and summer (see significant interaction term Time $\times$ Depth in Table 2). Young and juvenile fish were present at much lower densities than adults and appeared mostly in summer (Fig. 2). During the summer months, fish were heterogeneously distributed at a depth of $5 \mathrm{~m}$ (Table 3), being significantly more abundant in Area A than in the other areas (Table 4, SNK).

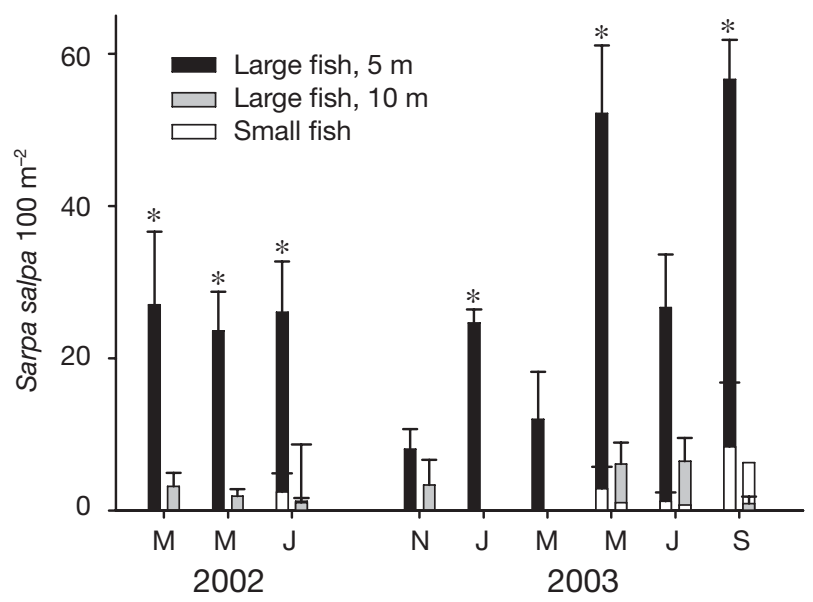

Fig. 2. Sarpa salpa. Time course of fish density (ind. $100 \mathrm{~m}^{-2}$; mean $+\mathrm{SE}$ ) of large (i.e. adults: TL $\geq 13 \mathrm{~cm}$ ) and small (i.e. young and juvenile: TL $<6$ to $12 \mathrm{~cm}$ ) fish at depths of 5 (left column) and $10 \mathrm{~m}$ (right column). *: statistically significant differences between depths 
Table 2. Sarpa salpa. Summary of the factorial 2-way ANOVA to assess differences in fish densities (adult ind. $100 \mathrm{~m}^{-2}$ ) between times, the 2 depths ( 5 and $10 \mathrm{~m}$ ), and their interactions. MS: mean square; df: degrees of freedom

\begin{tabular}{|lcrrr|}
\hline Effect & df & MS & \multicolumn{1}{c|}{$F$} & \multicolumn{1}{c|}{ p } \\
\hline Adult fish (i.e. $\geq \mathbf{1 3} \mathbf{~ c m})^{\text {a }}$ & & & \\
Time & 8 & 10 & 5.2 & $<0.001$ \\
Depth & 1 & 329 & 168.8 & $<0.001$ \\
Time $\times$ Depth & 8 & 6 & 3.0 & 0.006 \\
Error & 67 & 1.9 & & \\
a Data transformed to square root & & \\
\multicolumn{4}{l}{} \\
\hline
\end{tabular}

Table 3. Sarpa salpa. Mean and SEs for fish density (ind. $100 \mathrm{~m}^{-2}$ ) recorded at the seagrass meadow at a $5 \mathrm{~m}$ depth in summer months in the 3 areas (A, B, C, see Fig. 1)

\begin{tabular}{|lllc|}
\hline Area & July 2002 & July 2003 & September 2003 \\
\hline A & $42.8(14.7)$ & $44.2(19.6)$ & $106.2(20.4)$ \\
B & $31.0(16.9)$ & $17.8(4.2)$ & $38.6(18.1)$ \\
C & $11.7(4.6)$ & $22.8(5.4)$ & $50.3(10.3)$ \\
\hline
\end{tabular}

\section{Herbivore pressure}

Grazing marks on Posidonia oceanica leaves were mostly due to the 2 macroherbivores, the sea urchin Paracentrotus lividus and the fish Sarpa salpa, whereas attacks by other herbivores were rare $(<1 \%$ of all bites recorded). Fish grazing marks were quite abundant all year round, regardless of depth (Fig. 3a), with values ranging from 65 to 100 and 55 to $100 \%$ of collected shoots bitten by fish at depths of 5 and $10 \mathrm{~m}$, respectively. In summer, the percentage of shoots with fish bites was always above $80 \%$. Grazing marks left by sea urchins were less frequent and were only observed at a $5 \mathrm{~m}$ depth. The percentage of shoots with sea urchin bites ranged from 10 to $60 \%$, reaching highest values in winter/spring and lowest values in sum-

Table 4. Sarpa salpa. Summary of the factorial 2-way ANOVA to assess differences in fish densities (total ind. $100 \mathrm{~m}^{-2}$ ) at a $5 \mathrm{~m}$ depth between summer months (factor Time), the 3 areas (A, B, C, see Fig. 1), and their interactions. MS: mean square; df: degrees of freedom; ns: not significant. Results of SNK multiple mean comparison test for data are indicated

\begin{tabular}{|lrcccc|}
\hline $\begin{array}{l}\text { Variable } \\
\text { Effect }\end{array}$ & df & MS & $F$ & $p$ & SNK \\
\hline $\begin{array}{l}\text { Fish density } \\
\text { Time }\end{array}$ & 2 & 6724.9 & 6.714 & 0.003 & Sept 03 $>$ July 02 July 03 \\
Area & 2 & 6369.2 & 6.359 & 0.004 & A $>\underline{\text { BC }}$ \\
Time $\times$ Area & 4 & 1187.5 & 1.186 & ns & \\
Error & 36 & 1001.6 & & & \\
& & & & & \\
\hline
\end{tabular}

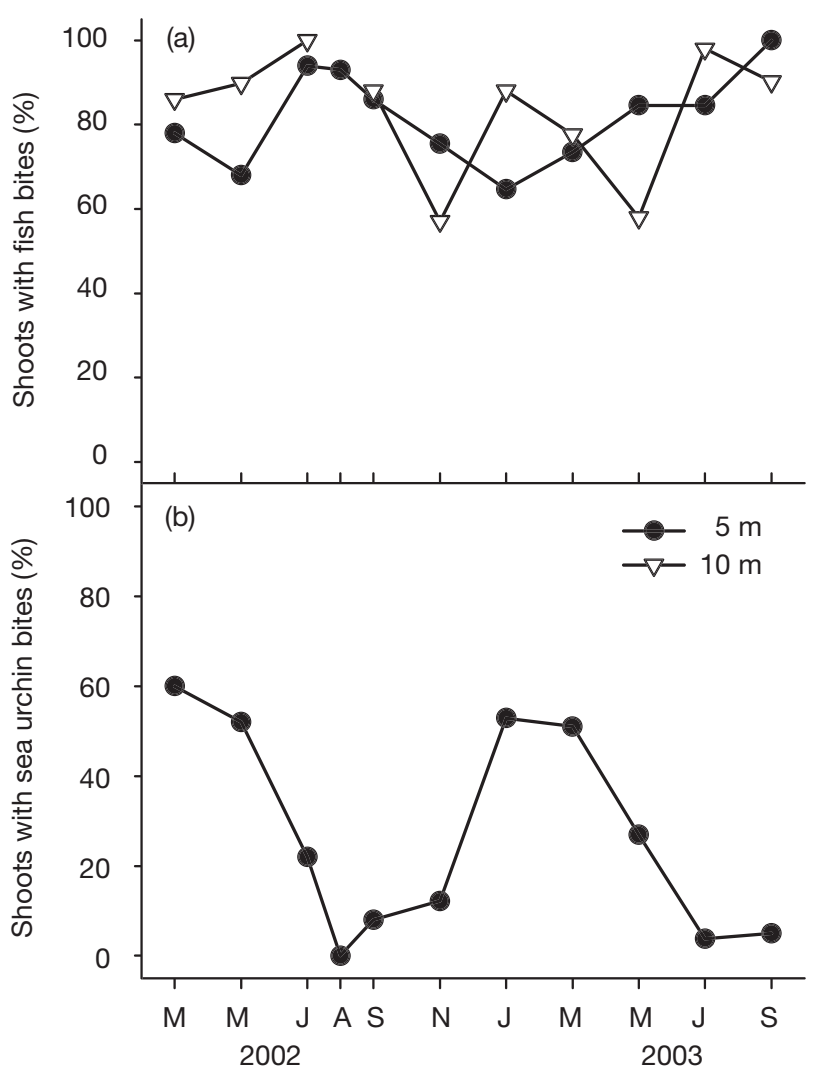

Fig. 3. Posidonia oceanica. Time course of herbivore pressure on $P$. oceanica expressed as the frequency of shoots with (a) fish bites and (b) sea urchin bites at depths of 5 and $10 \mathrm{~m}$

mer (Fig. 3b). Fish grazing, expressed as the number of fish bites $\mathrm{cm}^{-1}$ leaf, was generally higher at a $5 \mathrm{~m}$ than at a $10 \mathrm{~m}$ depth (Fig. 4a); these differences were more apparent during spring and summer (see significant interaction in Table 5). Total shoot length followed a pattern consistent with that of the fish bites, being generally shorter at $5 \mathrm{~m}$ than at $10 \mathrm{~m}$ (Fig. $4 \mathrm{~b}$ ), and with differences between depths being most important during spring and summer (see significant interaction in Table 5).

\section{Tethering experiment}

Tethered shoots were neither avoided nor preferentially consumed by Sarpa salpa, in comparison with unmanipulated shoots, as shown by the lack of significant differences in the number of fish bites per shoot recorded on tethered shoots and randomly collected shoots $(t=1.15$, df $=267, \mathrm{p}=$ $0.184)$. In fact, the frequency of shoots 

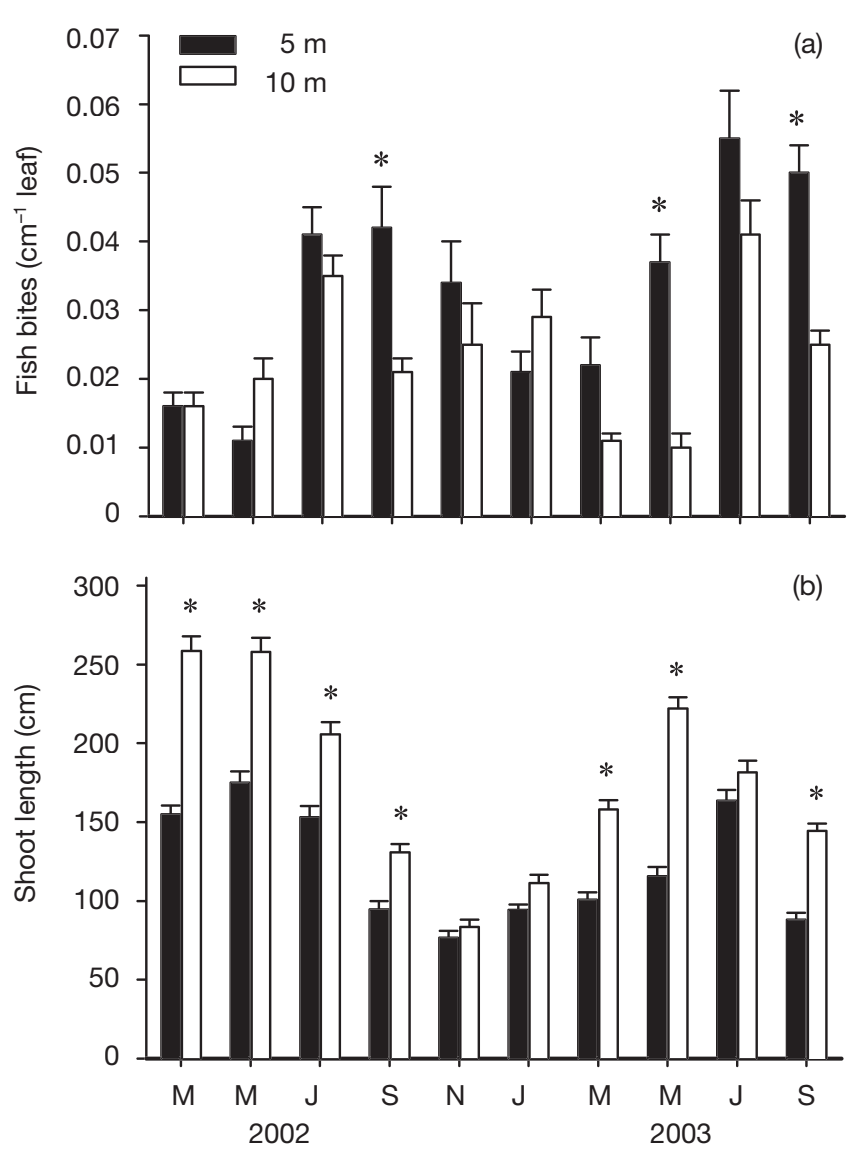

Fig. 4. Posidonia oceanica. Time course of herbivore pressure (mean $+\mathrm{SE}$ ) on P. oceanica as (a) fish bites (bites $\mathrm{cm}^{-1}$ leaf) and (b) shoot length $(\mathrm{cm})$. *: statistically significant differences between depths

with fish bites on tethered shoots (82.8\%) and unmanipulated shoots $(83.7 \%)$ was nearly identical.

The mean leaf removal rate by Sarpa salpa was 6.38 $\pm 0.50(\mathrm{SE}) \mathrm{cm}^{2}$ shoot $^{-1} \mathrm{~d}^{-1}$, whereas the mean removal rate by sea urchins was much lower $\left(0.11 \pm 0.06 \mathrm{~cm}^{2}\right.$ shoot $^{-1} \mathrm{~d}^{-1}$ ). During the experimental period, removal of leaf biomass by fish was ca. 20 times higher than the leaf production in the ungrazed plots, whereas removal by sea urchins was of the same order of magnitude as production (Fig. 5).

Sarpa salpa consumed $84.5 \%$ of the total shoot biomass loss estimated for the tethering experiment, whereas removal by sea urchins represented only $1.5 \%$ of total losses, and was in fact mostly observed during one of the experimental periods (between 1 and 11 August) in 1 area (B) (Fig. 5). Similarly, 83\% of the shoots placed during the experiment presented fish marks; $4 \%$ had sea urchin bites, $39 \%$ presented some breakage and only $7 \%$ remained intact. Fish grazing rate (\% of leaf area offered removed by $S$. salpa $\mathrm{d}^{-1}$ )
Table 5. Variability in herbivore pressure. Summary of the factorial 2-way ANOVA to assess differences in grazing pressure measurements between sampling times, depths (5 and $10 \mathrm{~m})$, and their interaction. MS: mean squares; df: degrees of freedom

\begin{tabular}{|c|c|c|c|c|}
\hline $\begin{array}{c}\text { Variable } \\
\text { Effect }\end{array}$ & df & MS & $F$ & $\mathrm{p}$ \\
\hline \multicolumn{5}{|c|}{ Fish bites $\left(\mathrm{cm}^{-1} \text { leaf }\right)^{\mathrm{a}}$} \\
\hline Time & 9 & 0.011 & 14.959 & $<0.001$ \\
\hline Depth & 1 & 0.023 & 30.425 & $<0.001$ \\
\hline Time $\times$ Depth & 9 & 0.004 & 5.237 & $<0.001$ \\
\hline Error & 956 & 0.001 & & \\
\hline \multicolumn{5}{|c|}{ Shoot length $(\mathrm{cm})^{\mathrm{b}}$} \\
\hline Time & 9 & 353 & 111.29 & $<0.001$ \\
\hline Depth & 1 & 1122 & 353.87 & $<0.001$ \\
\hline Time $\times$ Depth & 9 & 41 & 12.90 & $<0.001$ \\
\hline Error & 956 & 3.17 & & \\
\hline $\begin{array}{l}{ }^{\mathrm{a}} \text { Homogeneity } \\
{ }^{\mathrm{b}} \text { Data transform }\end{array}$ & $\begin{array}{l}\text { f vari } \\
\text { ed to }\end{array}$ & $\begin{array}{l}\text { ot ac } \\
\text { root }\end{array}$ & $\begin{array}{l}\text { ved } \\
+1)\end{array}$ & \\
\hline
\end{tabular}

varied significantly between lines (Table 6), indicating a heterogeneity at the scale of a few metres. A marginally significant interaction term between Time and Area (Table 6) indicates a slightly different time course in the 3 areas, with probably higher consumption in Area A during the 2 first experimental periods (Fig. 6a). Fish bites $\mathrm{cm}^{-1}$ leaf featured no significant pattern of variation for the factors analysed (Fig. 6b, Table 6).

From the consumption rates derived from the tethering experiment and measures of shoot density (see below), we estimated, in summer and at a $5 \mathrm{~m}$ depth, a seagrass consumption rate for Sarpa salpa (16.65 $\mathrm{g} \mathrm{DW} \mathrm{m}^{-2} \mathrm{~d}^{-1}$ ) which was between 1 and 2 orders of magnitude higher than the consumption rate estimated for Paracentrotus lividus (0.29 g DW

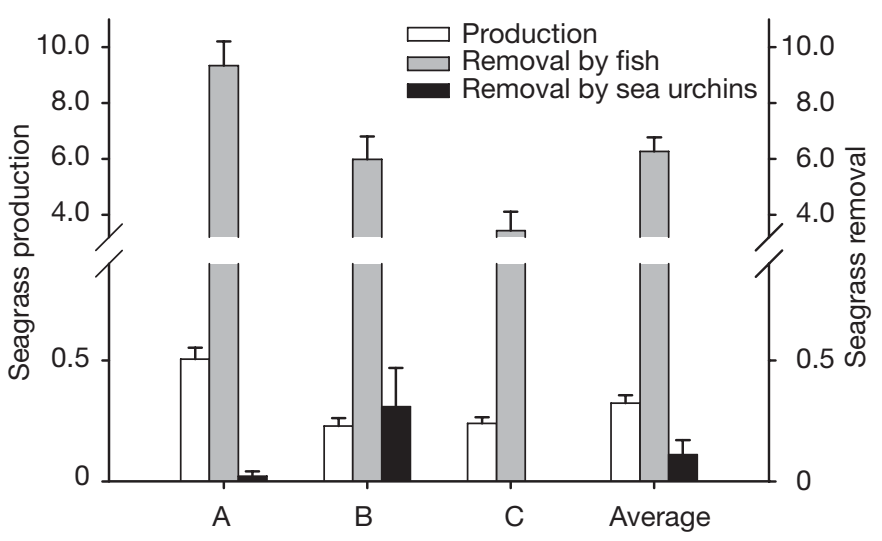

Fig. 5. Posidonia oceanica. Leaf area produced in ungrazed plots and removed by herbivores $\left(\mathrm{cm}^{2}\right.$ shoot $^{-1} \mathrm{~d}^{-1}$; mean $\left.+\mathrm{SE}\right)$ in summer 2002 at a $5 \mathrm{~m}$ depth 
Table 6. Summary of the nested ANOVA to assess differences in shoot variables in the tethering experiment between areas, sampling events (Time), lines (nested factor), and their interactions. MS: mean squares df degrees of freedom; ns: not significant

\begin{tabular}{|c|c|c|c|c|}
\hline $\begin{array}{c}\text { Variable } \\
\text { Effect }\end{array}$ & df & MS & $F$ & $\mathrm{p}$ \\
\hline \multicolumn{5}{|c|}{$\%$ leaf surface removed by fish $d^{-1}$} \\
\hline Time & 2 & 73.63 & 2.85 & ns \\
\hline Area & 2 & 94.44 & 3.65 & ns \\
\hline Time $\times$ Area & 4 & 25.85 & 2.58 & 0.072 \\
\hline Line $($ Time $\times$ Area) & 18 & 10.02 & 1.92 & 0.021 \\
\hline Error & 107 & 5.2 & & \\
\hline \multicolumn{5}{|l|}{ Fish bites $\left(\mathrm{cm}^{-1}\right)$} \\
\hline Time & 2 & 0.025 & 1.040 & ns \\
\hline Area & 2 & 0.034 & 1.409 & ns \\
\hline Time $\times$ Area & 4 & 0.024 & 2.132 & $\mathrm{~ns}$ \\
\hline Line (Time $\times$ Area) & 18 & 0.011 & 1.300 & ns \\
\hline Error & 107 & 0.009 & & \\
\hline
\end{tabular}

$\mathrm{m}^{-2} \mathrm{~d}^{-1}$ ) at the same depth and during the same period. For the time period studied (i.e. 30 d), seagrass removal by fish at a $5 \mathrm{~m}$ depth accounts for approximately $73 \%$ of the annual net aboveground primary production (NAPP, $252 \mathrm{~g} \mathrm{C} \mathrm{m}^{-2} \mathrm{yr}^{-1}$, Alcoverro et al. 1995), whereas removal by sea urchins accounts for ca. $1 \%$ of NAPP. The mean production during the time period studied at a $5 \mathrm{~m}$ depth was $0.31 \mathrm{~g} \mathrm{C} \mathrm{m}^{-2} \mathrm{~d}^{-1}$.

\section{Mowed patches}

Zones heavily grazed by Sarpa salpa (i.e. mowed patches) covered a large proportion of the meadow, especially in Area A, where the mowed surface was highest (Table 7) and where large mowed patches were more abundant (Fig. 7). In fact, the largest mowed patches $\left(>80 \mathrm{~m}^{2}\right.$, including one $\left.>300 \mathrm{~m}^{2}\right)$ were only encountered in Area A, whereas mowed patches $<1 \mathrm{~m}^{2}$ and between 1 and $5 \mathrm{~m}^{2}$, were the most frequent in Areas B and C. Overall, the dominant mowed

Table 7. Heavily fish-grazed areas (mowed patches) measured in 3 areas (A, B, C, see Fig. 1) at a $5 \mathrm{~m}$ depth during August 2002. Mean size $( \pm \mathrm{SE})$, total surface area, percentage cover within area and mean shoot density $( \pm \mathrm{SE})$

\begin{tabular}{|lcccc|}
\hline Area & $\begin{array}{c}\text { Mowed patch size } \\
\left(\mathrm{m}^{2}\right)\end{array}$ & $\begin{array}{c}\text { Surface } \\
\left(\mathrm{m}^{2}\right)\end{array}$ & \% surface & $\begin{array}{c}\text { Shoot density } \\
\left(\mathrm{m}^{-2}\right)\end{array}$ \\
\hline A & $29.6 \pm 15.5(\mathrm{n}=20)$ & 1085 & 54.5 & $707 \pm 42$ \\
B & $5.37 \pm 1.1(\mathrm{n}=48)$ & 991 & 26.0 & $690 \pm 55$ \\
C & $5.6 \pm 1.5(\mathrm{n}=27)$ & 490 & 31.0 & $638 \pm 96$ \\
Total & $10.5 \pm 3.4(\mathrm{n}=95)$ & 2636 & 38.0 & $664 \pm 37$ \\
\hline
\end{tabular}

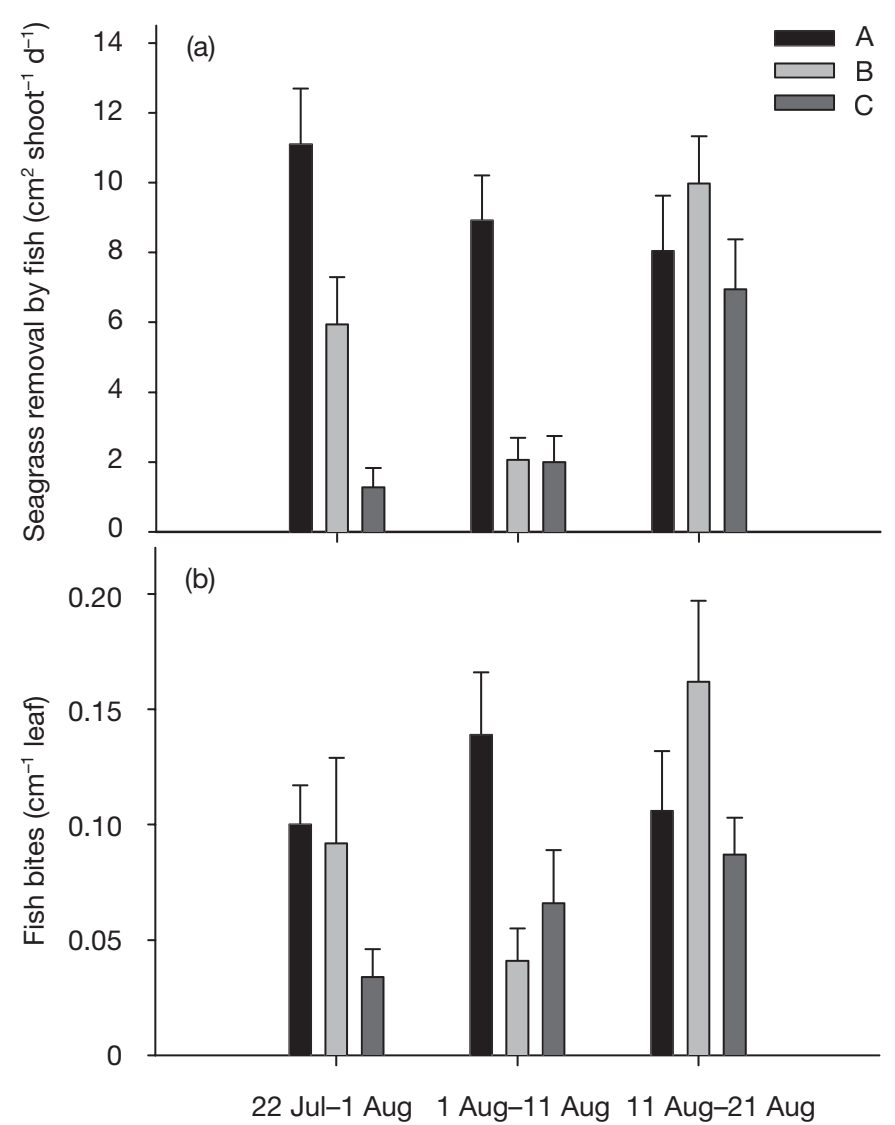

Fig. 6. Fish grazing pressure measured on tethered shoots expressed as (a) seagrass leaf area removed by the herbivorous fish Sarpa salpa $\left(\mathrm{cm}^{2}\right.$ shoot $^{-1} \mathrm{~d}^{-1}$; mean $\left.+\mathrm{SE}\right)$ and (b) fish bites (bites $\mathrm{cm}^{-1}$ leaf; mean $+\mathrm{SE}$ ) during summer 2002 within 3 distinct areas (A, B, C, see Fig. 1) at a $5 \mathrm{~m}$ depth

patches in the whole shallow meadow were between 1 and $5 \mathrm{~m}^{2}$ (Fig. 7).

Shoot size (both in terms of biomass and in terms of leaf area) was significantly lower in the mowed patches as compared to the ungrazed zones (Fig. 8, Table 8), whereas no differences were detected in epiphyte load per unit area, indicating that the loss of epiphytes was proportional to the loss of leaf tissue (Fig. 8, Table 8). Fish grazing, expressed as number of fish bites $\mathrm{cm}^{-1}$ leaf exhibited important spatial variability (significant factor Area, Table 8) and was significantly higher in the mowed patches than in the ungrazed plots (Fig. 8, significant factor Fish, Table 8). The fish bites in the exclusion cages occurred prior to the installation of the cages. The small-scale heterogeneity, represented by the factor Plot, contributed significantly to the overall variability in 


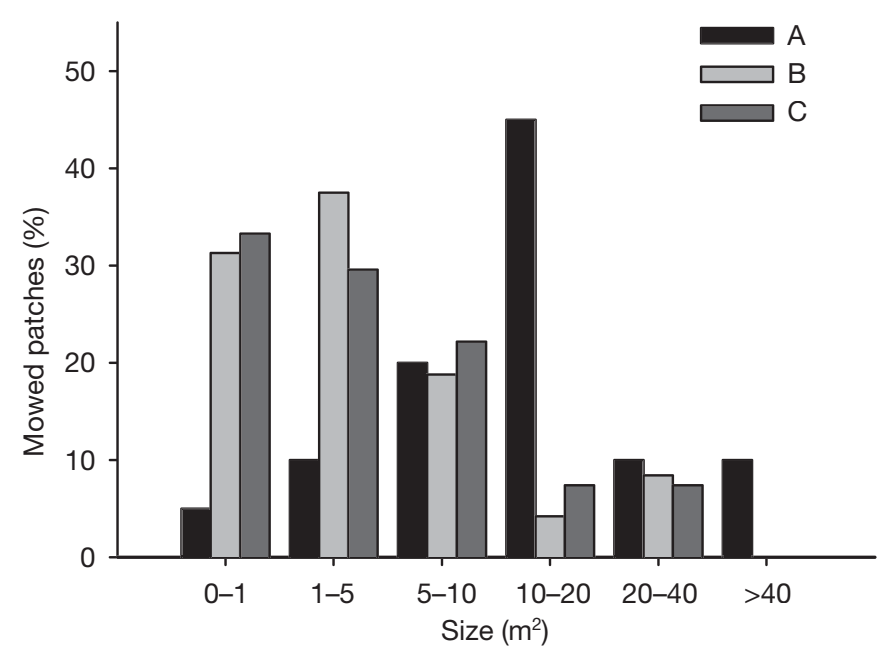

Fig. 7. Size frequency distribution of mowed patches measured between a depth of 5 and $6 \mathrm{~m}$ during August 2002 within 3 distinct areas (A, B, C, see Fig. 1)

all cases except for the number of fish bites. The only significant effect regarding leaf production was detected for Area A (significant interaction term, Table 9), in which leaf growth in plants from ungrazed areas was about double that in plants from the mowed patches (Fig. 8).

\section{DISCUSSION}

Our results show that grazing by the sparid fish Sarpa salpa can be substantial on shallow undisturbed Posidonia oceanica meadows. Conversely, the role of the sea urchin Paracentrotus lividus is comparatively minor, at least under the conditions of our study. Fish grazing, although highly variable in both space and time, greatly exceeded seagrass leaf growth during the studied period, thus causing a clear decrease in shoot biomass during summer in distinct areas of the meadow (mowed patches). Grazing by urchins, even if much less than that of fish, can still be substantial (ca. 15\% of annual NAPP, assuming no seasonality in consumption).

Fish grazing in the mowed patches significantly reduced leaf area and leaf biomass by approximately $50 \%$, and caused a reduction in leaf growth in 1 experimental area (Area A), where the highest leaf consumption by fish was recorded. The mowed patches did not persist in seasons other than summer (F. Tomas pers. obs.), indicating that seagrass can recover quickly from intense fish grazing. During the time of the year when mowed patches appear, most of the carbon fixed in leaves is devoted to accumulation of carbohydrate reserves rather than to leaf elongation (Alcoverro et al. 2001); hence, such strong reduction in leaf tissue probably decreases the seagrass capacity to store carbohydrates. Considering that the area of strong grazing comprised approximately $38 \%$ of the area surveyed between depths of 5 and $6 \mathrm{~m}$ (ca. $2600 \mathrm{~m}^{2}$ ), the reduction in shoot biomass is probably not negligible in terms of the carbon balance of the overall shallow part of the meadow, with potential negative effects for overwintering (Alcoverro et al. 2001). In addition, it has to be taken into account that these clonal plants redistribute resources (e.g. carbohydrates, nutrients) through the rhizome network (Libes \& Boudouresque 1987, Marbà et al. 2002), but only over small distances (15 to $20 \mathrm{~cm}$, Marbà et al. 2002). Yet, the dimension of most of the mowed patches thoroughly exceeded these transport distances, supporting the notion of a negative effect on plant reserves. Specific studies should clarify such effects of intense fish grazing on seagrass vitality in the longer term.
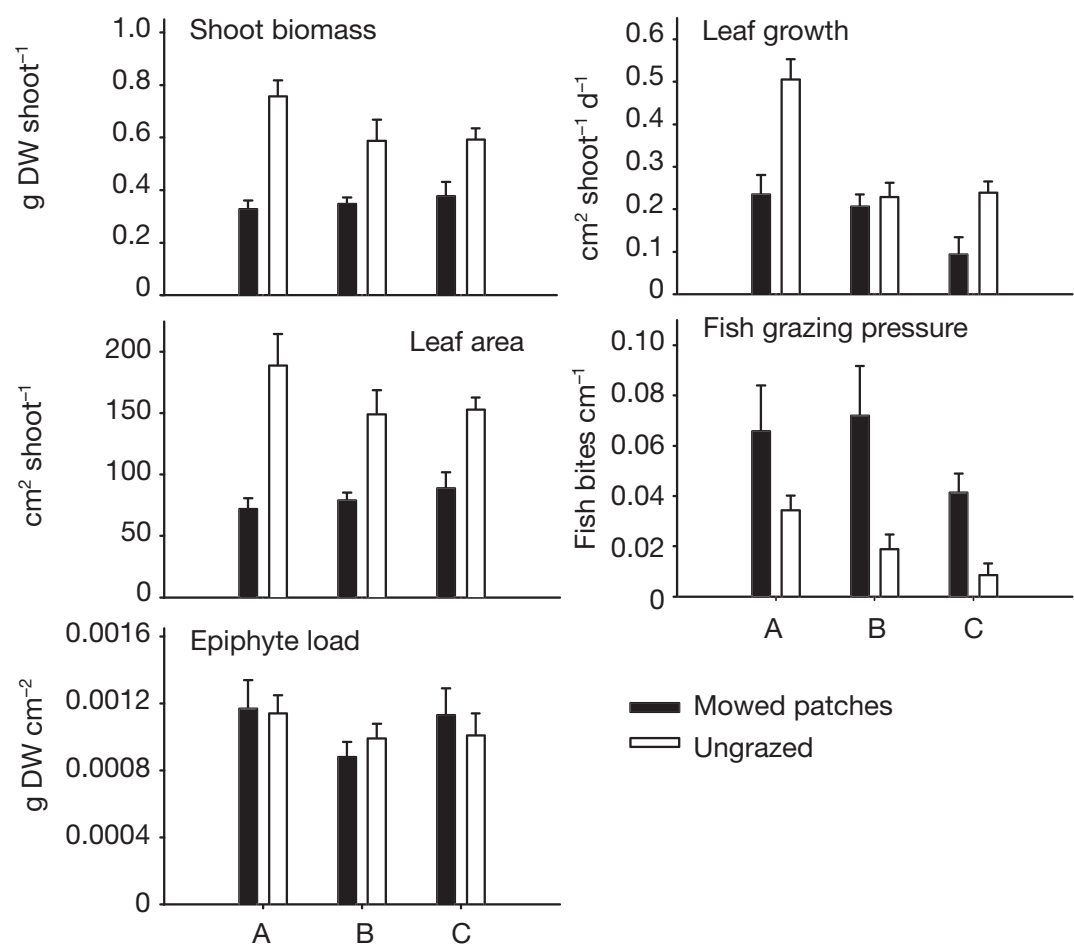

Fig. 8. Seagrass and epiphyte vitality (mean + SE) expressed as shoot biomass ( $\mathrm{g} \mathrm{DW}$ shoot $\left.{ }^{-1}\right)$, leaf area $\left(\mathrm{cm}^{2}\right.$ shoot $\left.{ }^{-1}\right)$, epiphyte load $\left(\mathrm{g} \mathrm{DW} \mathrm{cm}^{-2}\right)$ and leaf growth $\left(\mathrm{cm}^{2}\right.$ shoot $\left.{ }^{-1} \mathrm{~d}^{-1}\right)$, and fish grazing pressure measured by fish bites (bites $\mathrm{cm}^{-1}$ leaf) in mowed patches (black bars) and ungrazed plots (white bars) in August 2002. DW: dry weight 
Table 8. Summary of the nested ANOVA to assess differences in shoot variables between strongly fish grazed areas (mowed patches) and ungrazed areas (factor Fish), between areas (factor Area), and plots (nested factor), and their interactions. MS: mean square; df: degrees of freedom; ns: not significant

\begin{tabular}{|c|c|c|c|c|}
\hline $\begin{array}{c}\text { Variable } \\
\text { Effect }\end{array}$ & $\mathrm{df}$ & MS & $F$ & $\mathrm{p}$ \\
\hline \multicolumn{5}{|c|}{ Shoot biomass (g DW shoot ${ }^{-1}$ ) } \\
\hline Fish & 1 & 1.18 & 19.06 & 0.049 \\
\hline Area & 2 & 0.03 & 0.47 & $\mathrm{~ns}$ \\
\hline Fish $\times$ Area & 2 & 0.06 & 1.05 & $\mathrm{~ns}$ \\
\hline Plot (Fish × Area) & 12 & 0.06 & 4.56 & $<0.001$ \\
\hline Error & 36 & 0.01 & & \\
\hline \multicolumn{5}{|c|}{ Leaf area $\left(\mathrm{cm}^{2}\right.$ shoot $\left.^{-1}\right)$} \\
\hline Fish & 1 & 94359 & 25.09 & 0.038 \\
\hline Area & 2 & 1196 & 0.23 & ns \\
\hline Fish $\times$ Area & 2 & 3760 & 0.71 & ns \\
\hline Plot (Fish × Area) & 12 & 5290 & 4.80 & $<0.001$ \\
\hline Error & 36 & 1103 & & \\
\hline \multicolumn{5}{|c|}{ Epiphyte load (g DW $\mathrm{cm}^{-2}$ ) } \\
\hline Fish & 1 & $2.76 \mathrm{e}^{-7}$ & 0.047 & ns \\
\hline Area & 2 & $2.21 \mathrm{e}^{-7}$ & 0.793 & ns \\
\hline Fish $\times$ Area & 2 & $5.88 \mathrm{e}^{-7}$ & 0.211 & ns \\
\hline Plot (Fish × Area) & 12 & $2.79 \mathrm{e}^{-7}$ & 2.671 & 0.011 \\
\hline Error & 36 & $1.04 \mathrm{e}^{-7}$ & & \\
\hline \multicolumn{5}{|l|}{ Fish bites $\left(\mathrm{cm}^{-1} \text { leaf }\right)^{\mathrm{a}}$} \\
\hline Fish & 1 & 0.175 & 20.97 & 0.045 \\
\hline Area & 2 & 0.033 & 6.03 & 0.015 \\
\hline Fish $\times$ Area & 2 & 0.008 & 1.51 & $\mathrm{~ns}$ \\
\hline Plot (Fish × Area) & 12 & 0.006 & 0.97 & $\mathrm{~ns}$ \\
\hline Error & 36 & 0.006 & & \\
\hline \multicolumn{5}{|c|}{ a Data transformed to $\log (x+1)$} \\
\hline
\end{tabular}

Table 9. Posidonia oceanica. Summary of the 2-way ANOVA to assess differences in shoot production $\left(\mathrm{cm}^{2}\right.$ shoot $\left.^{-1} \mathrm{~d}^{-1}\right)$ between strongly fish grazed areas (mowed patches) and ungrazed areas (factor Fish), between areas (factor Area), and their interactions. MS: mean square; df: degrees of freedom; ns: not significant

\begin{tabular}{|c|c|c|c|c|}
\hline $\begin{array}{c}\text { Variable } \\
\text { Effect }\end{array}$ & $\mathrm{df}$ & MS & $F$ & $\mathrm{p}$ \\
\hline \multicolumn{5}{|c|}{ Shoot production $\left(\mathrm{cm}^{2} \operatorname{shoot}^{-1} \mathrm{~d}^{-1}\right)$} \\
\hline Fish & 1 & 0.2128 & 2.96 & ns \\
\hline Area & 2 & 0.1609 & 12.59 & $<0.001$ \\
\hline Fish $\times$ Area & 2 & 0.0718 & 5.62 & 0.007 \\
\hline Error & 45 & 0.0128 & & \\
\hline
\end{tabular}

When we compare the information gleaned through direct and indirect methods, it is worth noticing that the use of direct methods to evaluate seagrass grazing has provided us with important new information, which would have been overlooked through indirect measurements. Although the percentage of shoots with herbivore bites can give a relatively good idea of temporal or depth variation in grazing pressure (e.g.
Alcoverro et al. 1997, Peirano et al. 2001), it would not have allowed us to detect the strong fish grazing activity and formation of mowed patches taking place during the summer months.

Measurements of fish populations also helped in identifying the fish grazing summer peak. Nevertheless, the frequency of bitten shoots does not always correlate well with herbivore population measurements. In fact, whereas we observed a strong seasonal pattern in the frequency of shoots with urchin bites, we know that sea urchin density in this meadow is very stable throughout the year (Tomas et al. 2004). The lowest percentages of shoots with sea urchin bites were detected when the frequency of fish bites was maximal (i.e. summer periods). As sea urchin populations are stable (Tomas et al. 2004), either sea urchins exhibit a strong seasonal feeding pattern (Régis 1979, Lozano et al. 1995) and/or fish bites have a masking effect on sea urchin grazing measurements. Since sea urchins feed on the tips of the leaves (Boudouresque \& Verlaque 2001), when fish bite the plant, they can cut away the leaves and hence the mark left by sea urchins is lost. Therefore, indirect measurements are probably misleading regarding the relative importance of different herbivores. For example, even though the percentage of shoots with urchin bites in summer was very low (around 10\%), using direct methods we detected substantial consumption rates by the herbivore during this period. Problems with other indirect indicators of grazing such as shoot length also arise, since we cannot, with certainty, attribute shorter leaves to a higher grazing pressure or to (or in combination with) other factors such as light or nutrient availability, hydrodynamic regime, etc.

It becomes apparent that estimation of consumption rates by indirect methods (e.g. Cebrián \& Duarte 1998) can grossly underestimate the importance of herbivory in Posidonia oceanica. Using direct methods, we have obtained daily seagrass consumption rates by fish (16.65 $\mathrm{g} \mathrm{DW} \mathrm{m}^{-2} \mathrm{~d}^{-1}$ ) between 2 and 3 orders of magnitude higher than those estimated by Cebrián et al. (1996) in the same meadow (approximately $0.05 \mathrm{~g} \mathrm{DW}$ $\mathrm{m}^{-2} \mathrm{~d}^{-1}$ ) through indirect measurements. However, the differences observed may not only be the result of different methodological approaches. Indeed, our measurements were carried out approximately $8 \mathrm{yr}$ after the above mentioned work and hence, many variables influencing fish grazing activity (e.g. fish abundance) could have undergone considerable changes. In addition, Cebrián's estimates were not carried out in the same time period (June to July) as ours (August), and since Sarpa salpa appears to have a strong peak of activity in late summer, their data would not have captured this phenomenon. Until now, the importance of grazing in Posidonia oceanica food webs was consid- 
ered minor since herbivores were estimated (through indirect measurements) to consume, on average, only $2 \%$ of seagrass annual primary production (Cebrián et al. 1996). For the time period studied (i.e. $30 \mathrm{~d}$ in summer), we obtained consumption rates which reveal that at least ca. $70 \%$ of annual primary production is consumed by herbivores. Similar discrepancies between direct and indirect measurements of herbivory have been found in terrestrial systems (e.g. Lowman 1984, 1992), which also highlights the need to use direct methods, whenever possible, for a realistic estimation of herbivore pressure.

The fish consumption rates obtained in summer are probably the highest actually occurring in the meadow throughout the year, and they are coincident with a period of slow growth of the seagrass and restricted to specific areas in shallow waters. This results in the seasonal occurrence of mowed patches, but apparently does not affect the persistence of the seagrass meadows. In fact, the meadow studied has persisted for decades (Romero et al. 2001), implying that the seagrass can sustain the high levels of herbivory measured, may be in part due to its heterogeneity. Even if restricted to a short time span with respect to the life of the seagrass, our study already detected strong temporal and spatial heterogeneity in grazing. As in the case of many other marine herbivores (e.g. Odgen et al. 1973, Bjorndal 1980, Hay 1984, Alcoverro \& Mariani 2002, Kirsch et al. 2002), our study shows that Sarpa salpa does not graze uniformly, either temporally or spatially. Indeed, we observed a strong heterogeneous pattern (temporal, bathymetric and spatial) in fish abundance and feeding behaviour, thus distributing and 'diluting' the grazing impact on an annual (or pluriannual) basis. Observations on a wider temporal scale are necessary to substantiate this assumption.

To what extent our results represent a general feature of undisturbed Mediterranean seagrass meadows remains open to discussion. On the one hand, as in other Posidonia oceanica meadows, densities of Paracentrotus lividus found were quite low and fairly constant, and restricted to shallow regions (e.g. Azzolina et al. 1985, Ballesteros 1987, San Martin 1995, this study). On the other hand, it is true that this meadow is located in a marine protected area, and therefore fish density and biomass are higher than at nearby unprotected zones (Macpherson et al. 2002). However, Sarpa salpa densities close to those obtained in this study are frequently found in shallow Posidonia oceanica meadows of the NW Mediterranean (e.g. Harmelin-Vivien 1984, Velimirov 1984, Francour 1997, Ruiz 2000). In addition, the extensive work of Cebrián et al. (1996) and Alcoverro et al. (1997) also indicate the predominance of $S$. salpa as the main seagrass herbivore in the
Spanish Mediterranean. Furthermore, intense grazing by $S$. salpa and the formation of mowed patches appear to be a relatively common phenomenon in shallow $P$. oceanica meadows during summer (e.g. Laborel-Deguen \& Laborel 1977, Velimirov 1984, Verlaque 1990).

Direct measurements of seagrass consumption have revealed that herbivore pressure in present-day shallow Posidonia oceanica meadows can be substantial, and much higher than previously estimated. Although, as seen, fish grazing activity is remarkably heterogeneous, differences in results obtained by different approaches are noteworthy and leads us to strongly advocate the use of direct methods whenever possible. Overall, this work provides new experimental evidence supporting the notion that herbivory plays an important role in the dynamics of shallow nearshore seagrass habitats.

Acknowledgements. This work was supported by grant REN2002-04020-C02-02/MAR and GRC 2001 SGR 00093. The authors wish to thank B. Hereu, J. M. Ruiz, O. Mascaró, B. Comellas, B. Martínez and A. Vergés for field and laboratory assistance.

\section{LITERATURE CITED}

Alcoverro T, Mariani S (2002) Effects of sea urchin grazing on seagrass (Thalassodendron ciliatum) beds of a Kenyan lagoon. Mar Ecol Prog Ser 226:255-263

Alcoverro T, Duarte C, Romero J (1995) Annual growth dynamics of Posidonia oceanica: contribution of largescale versus local factors to seasonality. Mar Ecol Prog Ser 120:203-210

Alcoverro T, Duarte C, Romero J (1997) The influence of hervibores on Posidonia oceanica epiphytes. Aquat Bot 56: 93-104

Alcoverro T, Manzanera M, Romero J (2000) Nutrient mass balance of the seagrass Posidonia oceanica: the importance of nutrient retranslocation. Mar Ecol Prog Ser 194: $13-21$

Alcoverro T, Manzanera M, Romero J (2001) Annual metabolic carbon balance of the seagrass Posidonia oceanica (L.) Delile: the importance of carbohydrate reserves. Mar Ecol Prog Ser 211:105-116

Azzolina JF, Boudouresque CF, Nedelec H (1985) Dynamique des populations de Paracentrotus lividus dans la baie de Port-Cros (Var): données préliminaires. Trav Sci Parc Nation Port-Cros 11:61-81

Ballesteros E (1987) Distribución de Paracentrotus lividus (LMK.) y Arbacia lixula (L.) (Echinodermata, Echinoidea) en la zona infralitoral de la Costa Brava. Cuad Marisq Publ Téc 11:225-232

Bjorndal KA (1980) Nutrition and grazing behaviour of the green turtle Chelonia mydas. Mar Biol 56:147-154

Boudouresque CF, Meinesz A (1982) Découverte de l'herbier de Posidonies, Vol 4. Parc National de Port-Cros, Hyères

Boudouresque CF, Verlaque M (2001) Ecology of Paracentrotus lividus. In: Lawrence JM (ed) Edible sea urchins: biology and ecology, Vol 32. Elsevier Science, Amsterdam, p $177-216$ 
Cebrián J, Duarte CM (1998) Patterns of leaf herbivory on seagrasses. Aquat Bot 60:67-82

Cebrián J, Duarte CM, Marbà N, Enríquez S, Gallegos M, Olesen B (1996) Herbivory on Posidonia oceanica: magnitude and variability in the Spanish Mediterranean. Mar Ecol Prog Ser 130:147-155

Francour P (1997) Fish assemblages of Posidonia oceanica beds at Port-Cros (France, NW Mediterranean): assessment of composition and long-term fluctuations by visual census. PSZN I: Mar Ecol 18:157-173

García-Rubies A (1997) Estudi ecòlogic de les poblacions de peixos litorals sobre sustracte rocòs a la Mediterrània Occidental. PhD dissertation, University of Barcelona

García-Rubies A (1999) Effects of fishing on community structure and on selected populations of Mediterranean coastal reef fish. Naturalista Siciliana 23(Suppl):59-81

García-Rubies A, Zabala M (1990) Effects of total fishing prohibition on the rocky fish assemblages of Medes Islands marine reserve (NW Mediterranean). Sci Mar 54: $317-328$

Harmelin-Vivien ML (1984) Ichtyofaune des herbiers de Posidonies du Parc nature Regionel de Corse. In: Boudouresque CF, Jeudy de Grissac A, Olivier J (eds) International Workshop Posidonia oceanica Beds. GIS Posidonie, Marseille, p 291-301

Harmelin-Vivien M, Harmelin JG, Chauvet C, Duval C and 7 others (1985) Evaluation visuelle des peuplements et populations de poissons: methodes et problemes. Rev Ecol (Terre Vie) 40:467-539

Havelange S, Lepoint G, Dauby P, Bouquegneau JM (1997) Feeding of the sparid fish Sarpa salpa in a seagrass ecosystem: diet and carbon flux. PSZN I: Mar Ecol 18: 289-297

Hay ME (1984) Patterns of fish and urchin grazing on Caribbean coral reefs: Are previous results typical? Ecology 65: 446-454

Kirsch KD, Valentine J, Heck KLJ (2002) Parrotfish grazing on turtlegrass Thalassia testudinum: evidence for the importance of seagrass consumption in food web dynamics of the Florida Keys National Marine Sanctuary. Mar Ecol Prog Ser 227:71-85

Laborel-Deguen F, Laborel J (1977) Broutage des posidonies a la plage du sud. Trav Sci Parc Nation Port-Cros 3:213-214

Laevastu T, Hayes ML (1981) Fisheries oceanography and ecology. Fishing New Books, Surrey

Libes M, Boudouresque CF (1987) Uptake and long-distance transport of carbon in the marine phanerogam Posidonia oceanica. Mar Ecol Prog Ser 38:177-186

Lowman MD (1984) An assessment of techniques for measuring herbivory: Is rainforest defoliation more intense than we thought? Biotropica 16:264-268

Lowman MD (1992) Leaf growth dynamics and herbivory in five species of Australian rain-forest canopy trees. J Ecol 80:433-447

Lozano J, Galera J, López S, Turon X, Palacín C, Morera G (1995) Biological cycles and recruitment of Paracentrotus lividus (Echinodermata: Echinoidea) in two contrasting habitats. Mar Ecol Prog Ser 122:179-191

Maciá S (2000) The effects of sea urchin grazing and drift algal blooms on a subtropical seagrass bed community. J Exp Mar Biol Ecol 246:53-67

MacPherson E, Gordoa A, García-Rubies A (2002) Biomass size spectra in littoral fishes in protected and unprotected areas in the NW Mediterranean. Estuar Coast Shelf Sci 55: 777-788

Manzanera M, Alcoverro T, Romero J (1998) The role of the remnant leaf sheaths (scales) attached to the Posidonia oceanica (L.) Delile rhizomes. J Exp Mar Biol Ecol 223: $257-270$

Marbà N, Hemminga MA, Mateo MA, Duarte CM, Mass YEM, Terrados J, Gacia E (2002) Carbon and nitrogen translocation between seagrass ramets. Mar Ecol Prog Ser 226:287-300

Mariani S, Alcoverro T (1999) A multiple-choice feedingpreference experiment utilising seagrasses with a natural population of herbivorous fishes. Mar Ecol Prog Ser 189: 295-299

McGlathery KJ (1995) Nutrient and grazing influences on a subtropical seagrass community. Mar Ecol Prog Ser 122: 239-252

Nienhuis PH, Groenendijk AM (1986) Consumption of eelgrass (Zostera marina) by birds and invertebrates: an annual budget. Mar Ecol Prog Ser 29:29-35

Nienhuis PH, Van Ierland ET (1978) Consumption of eelgrass, Zostera marina, by birds and invertebrates during the growing season in lake Grevelingen (SW Netherlands). Neth J Sea Res 12:180-194

Odgen JC, Brown RA, Salesky N (1973) Grazing by the Echinoid Diadema antillarum Philippi: formation of halos around Wet Indian Patch Reefs. Science 182:715-716

Peirano A, Niccolai I, Mauro R, Bianchi CN (2001) Seasonal grazing and food preference of herbivores in a Posidonia oceanica meadow. Sci Mar 65:367-374

Régis MB (1979) Analyse des fluctuations des indices physiologiques chez deux échinoides (Paracentrotus lividus (Lmk) et Arbacia lixula L.) du golfe de Marseille. Tethys 9 (2):167-181

Romero J (1989) Seasonal pattern of Posidonia oceanica production: growth, age and renewal of leaves. In: Boudouresque CF, Meinesz A, Fresi E, Gravez V (eds) International Workshop on Posidonia Beds, Vol 2. GIS Posidonie, Marseille, p 63-68

Romero J, Pérez M, Renom P, Invers O, Mateo MA, Tomas F, Manzanera M, dePedro X (1999) Seguimiento de la pradera de Posidonia oceanica de las Islas Medes. Ejercicio de 1999. In: Zabala (ed) Seguiment Temporal de les Illes Medes. Exercici 1999. Departament de Medi Ambient, Generalitat de Catalunya, Barcelona, p 9-18

Romero J, Pérez M, Renom P (2001) Seguimiento de la pradera de Posidonia oceanica de las Islas Medes. Ejercicio de 2001. In: Zabala (ed) Seguiment temporal del l'area marina protegida de les Illes Medes: informe anual. Any 2001. Departament de Medi Ambient, Generalitat de Catalunya, Barcelona, p 39-44

Ruiz JM (2000) Respuesta de la fanerógama marina Posidonia oceanica (L.) Delile a perturbaciones antrópicas. $\mathrm{PhD}$ dissertation, Universidad de Murcia, Murcia

Ruiz JM, Romero J (2001) Effects of in situ experimental shading on the Mediterranean seagrass Posidonia oceanica. Mar Ecol Prog Ser 215:107-120

Ruiz JM, Pérez M, Romero J (2001) Effects of fish farm loading on seagrass (Posidonia oceanica): distribution, growth and photosynthesis. Mar Pollut Bull 42:749-760

San Martin G (1995) Contribution a la gestion des stocks d'oursins: etude des populations et transplantantations de Paracentrotus lividus a Marseille (France, Mediterranee) et production de Loxechinus albus a Chiloe (Chili, Pacifique). Université d'Aix-Marseille II, Marseille

Spyker KA, Van den Berghe EP (1995) Diurnal abundance patterns of Mediterranean fishes assessed on fixed transects by scuba divers. T Am Fish Soc 124:216-224

Thayer GW, Bjorndal KA, Odgen JC, Williams SL, Zieman JC (1984) Role of larger herbivores in seagrass communities. Estuaries 7:351-376 
Tomas F, Romero J, Turon X (2004) Settlement and recruitment of the sea urchin Paracentrotus lividus in two contrasting habitats in the Mediterranean. Mar Ecol Prog Ser 282:173-184

Tomas F, Turon X, Romero J (2005) Effects of herbivores in a Posidonia ocenica seagrass meadow: importance of epiphytes. Mar Ecol Prog Ser 287:115-125

Traer K (1980) The consumption of Posidonia oceanica Delile by echinoids at the isle of Ischia. In: Jangoux M (ed) Europ colloq echinoderms 'Echinoderms: present and past'. Balkema, Rotterdam, p 241-242

Underwood AJ (1997) Experiments in ecology. Cambridge University Press, Cambridge

Valentine JF, Heck KLJ (1999) Seagrass herbivory: evidence for the continued grazing of marine grasses. Mar Ecol Prog Ser 176:291-302

Valentine JF, Heck KLJ, Kirsch KD, Webb D (2000) Role of sea urchin Lytechinus variegatus grazing in regulating subtropical turtlegrass Thalassia testudinum meadows in the Florida Keys (USA). Mar Ecol Prog Ser 200:213-228

Editorial responsibility: Otto Kinne (Editor-in-Chief), Oldendorf/Luhe, Germany
Valiela I (1995) Marine ecological processes. Springer-Verlag, New York

Velimirov B (1984) Grazing of Sarpa salpa L. on Posidonia oceanica and utilization of soluble compounds. In: Boudouresque CF, Jeudy de Grissac A, Olivier J (eds) I International workshop on Posidonia oceanica beds. GIS Posidonie, Marseille, p 381-387

Verlaque M (1987) Relations entre Paracentrotus lividus (Lamarck) et le phytobenthos de Mediterranée occidentale. In: Boudouresque CF (ed) GIS Posidonie, Marseille, p 5-36

Verlaque M (1990) Relations entre Sarpa salpa (Linnaeus, 1758) (Téléostéen, Sparidae), les autres poissons broteurs et le phytobenthos algal méditerranéen. Oceanol Acta 13: 373-388

Verlaque M, Nédelec H (1983) Note préliminaire sur les relations biotiques Paracentrotus lividus (LMK.) et herbier de Posidonies. Rapp Comm Int Mer Médit 28:157-158

Zar JH (1989) Biostatistical analysis. Prentice-Hall, Englewood Cliffs, NJ

Submitted: May 10, 2004; Accepted: March 13, 2005

Proofs received from author(s): September 21, 2005 